\title{
High titer MVA and influenza A virus production using a hybrid fed-batch/perfusion strategy with an ATF system
}

\author{
Daniel Vázquez-Ramírez ${ }^{1}$ (D) • Ingo Jordan ${ }^{2} \cdot$ Volker Sandig $^{2} \cdot$ Yvonne Genzel $^{1} \cdot$ Udo Reichl $^{1,3}$
}

Received: 23 July 2018 /Revised: 13 January 2019 / Accepted: 15 January 2019 /Published online: 23 February 2019

(C) The Author(s) 2019

\begin{abstract}
A cultivation strategy to increase the productivity of Modified Vaccinia Ankara (MVA) virus in high-cell density processes is presented. Based on an approach developed in shake flask cultures, this strategy was established in benchtop bioreactors, comprising the growth of suspension AGE1.CR.pIX cells to high cell densities in a chemically defined medium before infection with the MVA-CR19 virus strain. First, a perfusion regime was established to optimize the cell growth phase. Second, a fed-batch regime was chosen for the initial infection phase to facilitate virus uptake and cell-to-cell spreading. Afterwards, a switch to perfusion enabled the continuous supply of nutrients for the late stages of virus propagation. With maximum infectious titers of $1.0 \times 10^{10} \mathrm{IU} / \mathrm{mL}$, this hybrid fed-batch/perfusion strategy increased product titers by almost one order of magnitude compared to conventional batch cultivations. Finally, this strategy was also applied to the production of influenza A/PR/8/34 (H1N1) virus considered for manufacturing of inactivated vaccines. Using the same culture system, a total number of $3.8 \times 10^{10}$ virions $/ \mathrm{mL}$ was achieved. Overall, comparable or even higher cell-specific virus yields and volumetric productivities were obtained using the same cultivation systems as for the conventional batch cultivations. In addition, most viral particles were found in the culture supernatant, which can simplify further downstream operations, in particular for MVA viruses. Considering the current availability of well-described perfusion/cell retention technologies, the present strategy may contribute to the development of new approaches for viral vaccine production.
\end{abstract}

Keywords Viral vaccine production $\cdot$ Process intensification $\cdot$ On-line monitoring

\section{Introduction}

Modified Vaccinia Ankara (MVA) virus is a highly attenuated poxvirus with promising properties as a vectored vaccine. MVA initiates but cannot complete a full replication cycle in human recipients and is therefore immunogenic similar to live

Electronic supplementary material The online version of this article (https://doi.org/10.1007/s00253-019-09694-2) contains supplementary material, which is available to authorized users.

Yvonne Genzel

genzel@mpi-magdeburg.mpg.de

1 Max Planck Institute for Dynamics of Complex Technical Systems, Sandtorstr. 1, 39106 Magdeburg, Germany

2 ProBioGen AG, Goethestr. 54, 13086 Berlin, Germany

3 Chair for Bioprocess Engineering, Otto-von-Guericke-University Magdeburg, Universitätsplatz 2, 39106 Magdeburg, Germany virus vaccines (Gomez et al. 2013) but with safety properties resembling inactivated virus vaccines (Gilbert et al. 2006; Cebere et al. 2006; Webster et al. 2005; Stickl et al. 1974; Mayr 2003). MVA recombinants expressing different viral heterologous antigens have been tested in pre-clinical and clinical trials as candidate vaccines against infectious diseases such as AIDS, influenza, severe acute respiratory syndrome (SARS), and human respiratory syncytial virus (RSV) infection (Boukhebza et al. 2012; Gilbert 2013; Gomez et al. 2011, 2012). Conventionally, MVA seed virus stocks considered for vaccine manufacturing are produced in chicken embryo fibroblast (CEF) that are fully permissive for MVA. Using wellestablished protocols (Altenburg et al. 2014; Cotter et al. 2017), large-scale production of MVA recombinants for immunization campaigns would also have to rely on propagation in CEF (Altenburg et al. 2014). However, because supply with the primary cell cultures can be challenging for large scale manufacturing, production of MVA recombinants is being investigated for continuous suspension cell lines, such as the 
duck cell lines AGE1.CR and AGE1.CR.pIX (Jordan et al. 2009; Lohr et al. 2009), or the duck embryonic stem cellderived EB66 cells (Léon et al. 2016).

Influenza viruses are usually processed to provide inactivated vaccines against seasonal epidemics (Soema et al. 2015). Production of influenza vaccines in the past 70 years relied on embryonated chicken eggs. Disadvantages associated with this substrate are the use of an animal-derived substrate and the potential shortage of eggs especially in case of a pandemic emergency. Recently, two cell culture-based vaccines produced either in MDCK cells or in insect cells using the baculovirus expression vector system were approved by the FDA (Buckland 2015). In addition, efficient production of influenza virus has also been shown for other suspension cell lines including Vero cells (Litwin 1992; Paillet et al. 2009), PER.C6 cells (Pau et al. 2001), HEK293 cells (Le Ru et al. 2010), EB66 cells (Brown and Mehtali 2010; White et al. 2018), and AGE1.CR as well as AGE1.CR.pIX cells (Jordan et al. 2013; Lohr et al. 2012; Lohr 2014).

Cell culture-derived viral vaccines are typically produced in biphasic processes. They comprise an initial cell growth phase and a virus replication phase that initiates with inoculation by seed virus. After the viral genome is amplified and viral proteins are produced, virions are assembled and progeny virus particles released (Aunins 2000). Typically, cells are first cultivated in batch mode and infected in the late exponential growth phase at concentrations in the order of $10^{5}-10^{6}$ cells $/ \mathrm{mL}$, with or without a partial exchange of culture medium (Aunins 2000; Tapia et al. 2016). Titers of wild-type MVA obtained in adherent cultures of CEF cells in serum-containing medium are in the range of $10^{7}-10^{9}$ infectious units (IU) per $\mathrm{mL}$ (Gilbert et al. 2005; Meiser et al. 2003). The avian cell lines AGE1.CR.pIX (Jordan et al. 2009; Lohr et al. 2009; Lohr 2014), EB14 (Guehenneux and Pain 2005) and EB66 (Léon et al. 2016) also yield titers in the order of $10^{8} \mathrm{IU} / \mathrm{mL}$ but with the advantage of enabling suspension cell culture processes. However, one caveat is that these processes require induction of suspended cell aggregates for efficient replication of MVA. A novel MVA derivative, MVA-CR19, was adapted to propagation in true single-cell suspension cultures without the requirement for addition of medium to induce cell aggregation (Jordan et al. 2013).

Scalable and intensified processes that yield high titers are desirable to secure adequate supply with vaccines. In the case of MVA, high virus titers are required because MVA does not replicate in human recipients and therefore is not amplified at the site of injection. Concentrated doses of $10^{8}-10^{9} \mathrm{IU} / \mathrm{mL}$ are estimated to be required for clinical applications of MVA (Gomez et al. 2013; Altenburg et al. 2014). In the case of influenza vaccines, intensification is desirable because composition of multivalent vaccines changes every year, and the time is short between selection of seasonal virus strains and desired start of vaccination.
Increasing the concentration of host cells is a standard approach to intensify production processes for biologicals. Processes at high cell density (HCD) allow the use of compact bioreactors with high volumetric production rates and can be adjusted to viable cell densities of $10^{7}-10^{8}$ per $\mathrm{mL}$ (Clincke et al. 2013). Such cell densities can be achieved in perfusion mode, which allows for a continuous addition of fresh medium and removal of toxic by-products (such as lactate and ammonium) while retaining cells in the bioreactor using different retention systems. The production of recombinant proteins in perfusion is typically performed at high-medium exchange rates of 1-3 media volumes per reactor volume per day (1/day) or $0.05-0.5 \mathrm{~nL} /($ cell $\times$ day) (Konstantinov et al. 2006). To maintain cultures in a proliferative state at constant high cell densities, a controlled and continuous removal of cells from the bioreactor is performed, the so-called "cell bleed" (Clincke et al. 2013; Deschênes et al. 2006; Hiller et al. 1993). Novel cultivation strategies such as n-1 perfusion/high-seed fed-batch (Yang et al. 2014), concentrated fed-batch (FB) (Yang et al. 2016), and hybrid perfusion FB (Hiller et al. 2017) have been developed to minimize media use while maintaining cell-specific and volumetric productivities as well as guaranteeing consistent product quality.

In the field of viral vaccine production, high cell concentrations up to $5 \times 10^{7}$ cells $/ \mathrm{mL}$ were used for the propagation of influenza A/PR/8/34 (H1N1) virus (Genzel et al. 2014) and the MVA-CR19 virus strain (Vazquez-Ramirez et al. 2018). At those cell concentrations, virus propagation must be performed at optimal $\mathrm{pH}$, temperature, and nutrient concentrations to avoid the so-called "cell density effect", a reduction in cell-specific virus yield often observed for concentrations exceeding $5 \times 10^{6}$ cells $/ \mathrm{mL}$ (Lindsay and Betenbaugh 1992; Maranga et al. 2003).

Several improvements were reported for the HCD production of influenza A/PR/8/34 (H1N1) virus. Cultivations were performed in perfusion cultures for both cell and virus propagation phases using an acoustic filter (Petiot et al. 2011) or an alternating tangential flow (ATF) system for cell retention (Genzel et al. 2014). The perfusion systems differed in the partitioning of the virus. Whereas the acoustic filter allowed a continuous virus harvest, ATF systems with membrane pores sizes $<0.5 \mu \mathrm{m}$ retained most released viral particles in the bioreactor. In addition, the continuous permeate flow through the hollow fiber membrane resulted in product losses due to unspecific binding or membrane fouling by entrapment of cellular debris and virus particles within the membrane pores (Genzel et al. 2014). Although cell-specific virus yields comparable to conventional batch processes were obtained for both cell retention systems, the volumetric productivity (the amount of virus per volume of medium spent and time) was lower (Genzel et al. 2014). This strategy would therefore be less competitive because of the increased cost of goods (COGs) for its implementation in large-scale (Pollock et al. 
2013). In an attempt to produce MVA virus (MVA-CR19 strain) at high concentrations in AGE1.CR.pIX cells $\left(5 \times 10^{7}\right.$ cells $/ \mathrm{mL}$ ), perfusion using a medium free of animal-derived components was implemented (Vazquez-Ramirez et al. 2018). This method resulted in virus retention and yielded lower cellspecific and volumetric productivities compared to conventional cell density cultivations. A detailed analysis of several cultivation strategies in shake flasks demonstrated that a FB phase followed by a daily medium exchange of $90 \%$ can result in an improvement of both cell-specific yield and volumetric productivity, even surpassing conventional cell density processes performed as a control (Vazquez-Ramirez et al. 2018). While shake flask experiments are essential for the characterization of production processes, they are insufficient for establishing strategies for large-scale manufacturing of vaccines.

Hence, in the present study, an optimized HCD process was developed in a controlled and scalable cultivation system to provide the required high yields of MVA virus. HCD cultures were achieved in a $1 \mathrm{~L}$ bioreactor with an ATF perfusion system using a manual perfusion control. Perfusion rates were adjusted applying a fixed cell-specific perfusion rate (CSPR), which is the volume of medium provided to a single cell per day (Ozturk 1996). During virus production, the cells were cultivated in FB followed by a continuous medium exchange with the same ATF perfusion system used for the cell proliferation phase (hybrid FB/perfusion strategy). Yields and productivity of this process confirmed shake flask results. To investigate options for the use of this strategy to other viral vaccine production processes, propagation of influenza A virus was also tested. Again, a similar or even higher productivity compared to conventional cell density cultivations was obtained.

\section{Materials and methods}

\section{Cells and medium}

The AGE1.CR.pIX cell line (here named CR.pIX) is directly derived from the avian cell line AGE1.CR, which was generated from Muscovy duck retina cells (Jordan et al. 2009). The CR.pIX cells differ from their progenitor AGE1.CR in that they express the pIX protein of human adenovirus (Jordan et al. 2009), a virus that is not related to MVA or influenza viruses. Suspension CR.pIX cells were cultivated in chemically defined CD-U3 medium (Biochrom $\mathrm{GmbH}$ ) with a glucose concentration of 33-40 mM, supplemented with glutamine (Sigma, Lot SLBS8600) and alanine (Sigma, Lot BCBS2461V) to a final concentration of $2 \mathrm{mM}$. In addition, recombinant insulin-like growth factor (LONG-R3IGF, Sigma, Lot LOS6008) was added at $10 \mathrm{ng} / \mathrm{mL}$ final concentration. Cells were passaged every $3-4$ days at a seed concentration of $0.8 \times 10^{6}$ cells $/ \mathrm{mL}$.

\section{Bioreactor cultivations}

CR.pIX cells were inoculated in a $1 \mathrm{~L}$ (nominal volume) benchtop bioreactor (BIOSTAT®B plus, Sartorius AG) at $0.8 \times 10^{6}$ cells $/ \mathrm{mL}$ in a working volume $\left(V_{\mathrm{w}}\right)$ of $0.6-0.8 \mathrm{~L}$

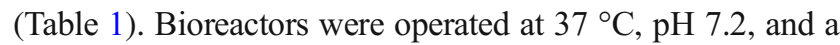
stirring speed of 120-160 rpm. Dissolved oxygen concentration (DO) was controlled at $40 \%$ by pulsed aeration with pure oxygen through a $20-\mu \mathrm{m}$ pore size micro-sparger unit to a maximum of $29-38 \mathrm{~cm}^{3} / \mathrm{min}$. Cells were initially cultivated in batch until a glucose concentration of 14-17 $\mathrm{mM}(60-72 \mathrm{~h}$ after inoculation) was reached. At that point, perfusion was started using an ATF2 perfusion system controlled by the C24U-V2.0 controller from Refine Technology and polysulfone hollow fiber cartridges with pore sizes of $500 \mathrm{kDa}$ (UFP-500-E-4X2MA, GE Healthcare) and $0.65 \mu \mathrm{m}$ (CFP-6-D-4X2MA, GE Healthcare), or polyethersulfone hollow fiber cartridges of $0.2 \mu \mathrm{m}$ (S06-P20U-10-S, Spectrum Labs) (Table 1). Cell suspension flow rate within the hollow fiber was set at $1.0 \mathrm{~L} / \mathrm{min}$, and defined perfusion rates were applied to achieve cell densities $>25 \times 10^{6}$ cells/ $\mathrm{mL}$.

Perfusion flow rates during the cell growth phase were adjusted manually every 12 or $24 \mathrm{~h}$. For that, viable cell densities were measured off-line, and the corresponding flow rates for that sampling time were calculated to assure a CSPR of $0.06 \mathrm{~nL} /($ cell $\times$ day), which is the optimal exchange rate for CR.pIX cells based on their glucose consumption rate (Vazquez-Ramirez et al. 2018). Expected viable cell densities and the corresponding perfusion flow rates after 12 or $24 \mathrm{~h}$ were calculated taking into account a maximum cell-specific growth rate of $\mu=0.026 \mathrm{~h}^{-1}$ (data not shown). A linear profile between sampling time points was achieved using the cascade control of the BIOSTAT ${ }^{B} B$ plus module. Two hours before infection, one reactor volume was exchanged with fresh medium using the ATF system. A summary of key parameters of all perfusion cultivations is presented in Table 1 .

After medium exchange, bioreactors were infected either with MVA-CR19 or influenza A virus A/PR/8/34 (H1N1). For MVA-CR19 virus, two bolus feeding regimes followed by a perfusion regime, namely Hybrid 1 (Fig. 1a) and Hybrid 2 (Fig. 1d), were applied to optimize virus propagation at high cell densities. For Hybrid 1, one-half of the cell suspension was discarded, and the virus production phase was started with $0.3 \mathrm{~L}$ of cell suspension to allow for a FB with a volume expansion up to threefold higher than its initial $V_{\mathrm{w}}$, as described before (Vazquez-Ramirez et al. 2018). The FB was started immediately after virus infection with the addition of $0.15 \mathrm{~L}$ of fresh medium to obtain the minimum culture volume at which the bioreactor impeller was at least $2 \mathrm{~cm}$ below the 
Table 1 Summary of process parameters and performance during the propagation of CR.pIX cells for all analyzed cultivations

\begin{tabular}{|c|c|c|c|c|c|c|c|}
\hline Cultivation & $\begin{array}{l}\text { Working } \\
\text { volume }[\mathrm{mL}]\end{array}$ & $\begin{array}{l}\text { Hollow fiber } \\
\text { module }\end{array}$ & $\begin{array}{l}\text { Initial VCD } \\
{\left[10^{6} \text { cells } / \mathrm{mL}\right]}\end{array}$ & $\mu_{\text {mean }}[1 / \mathrm{h}]$ & $\mu_{\max }[1 / \mathrm{h}]$ & $\begin{array}{l}\text { Actual average CSPR } \\
{[\mathrm{nL} /(\text { cell } \times \text { day })]}\end{array}$ & $\begin{array}{l}\text { Duration } \\
{[\mathrm{h}]^{* * *}}\end{array}$ \\
\hline \multicolumn{8}{|c|}{ MVA-CR19 virus } \\
\hline Perfusion* & 800 & $500 \mathrm{kDa}$ & 0.8 & $0.019(n=12, \mathrm{SD}=0.005)$ & 0.026 & $0.057(n=24, \mathrm{SD}=0.006)$ & 247 \\
\hline Hybrid 1 & 600 & $0.65 \mu \mathrm{m}$ & 1.0 & $0.021(n=12, \mathrm{SD}=0.006)$ & 0.029 & $0.068(n=18, \mathrm{SD}=0.013)$ & 191 \\
\hline Hybrid 2 & 600 & $0.20 \mu \mathrm{m}$ & 8.0 & $0.024(n=4, \mathrm{SD}=0.005)$ & 0.031 & $0.057(n=7, \mathrm{SD}=0.011)$ & 50 \\
\hline \multicolumn{8}{|c|}{ Influenza A virus } \\
\hline Perfusion & 800 & $500 \mathrm{kDa}$ & 1.0 & $0.017(n=18, \mathrm{SD}=0.011)$ & 0.055 & $0.072(n=24, \mathrm{SD}=0.010)$ & 183 \\
\hline Hybrid & 600 & $0.65 \mu \mathrm{m}$ & 1.0 & $0.019(n=7, \mathrm{SD}=0.004)$ & 0.025 & $0.119(n=20, \mathrm{SD}=0.061)^{* *}$ & 168 \\
\hline Batch & 800 & NA & 0.8 & $0.020(n=6, \mathrm{SD}=0.009)$ & 0.033 & NA & 82 \\
\hline
\end{tabular}

*Vazquez-Ramirez et al. (2018)

**Non-constant CSPR: perfusion rates were automatically adjusted to maintain the $\mathrm{pH}$ at a set point of 7.2 and not based on the actual viable cell densities

***Time from cells inoculation to infection

medium surface. The FB continued with bolus feedings of $0.15 \mathrm{~L}$ at $12 \mathrm{~h}$ post infection (hpi) and $0.3 \mathrm{~L}$ at $24 \mathrm{hpi}$. Finally, perfusion was performed at a rate of one reactor volume per day 36-120 hpi (Fig. 1a). MVA-CR19 virus particles (200-400 nm nominal size) were harvested using the same ATF hollow fiber module $(0.65 \mu \mathrm{m}$ pore size $)$ as in the cell growth phase.

Similarly, for Hybrid 2, one bolus feed of $0.2 \mathrm{~L}$ was done immediately after virus infection followed by a second feed of $0.25 \mathrm{~L}$ at $24 \mathrm{hpi}$. Subsequently, perfusion was again performed at a rate of one reactor volume per day 36 120 hpi (Fig. 1d). In order to improve the virus harvest, the $0.2-\mu \mathrm{m}$ ATF module used during the cell growth phase was replaced by a new $0.65-\mu \mathrm{m}$ module at $36 \mathrm{hpi}$.

For influenza A virus production, a hybrid strategy (Fig. 3a) similar to the one assessed for MVA-CR19 virus was established. Reference processes, one operated completely in perfusion with total virus retention and one in batch at conventional cell densities, were performed as proposed previously by Genzel et al. (2014). A detailed description of the
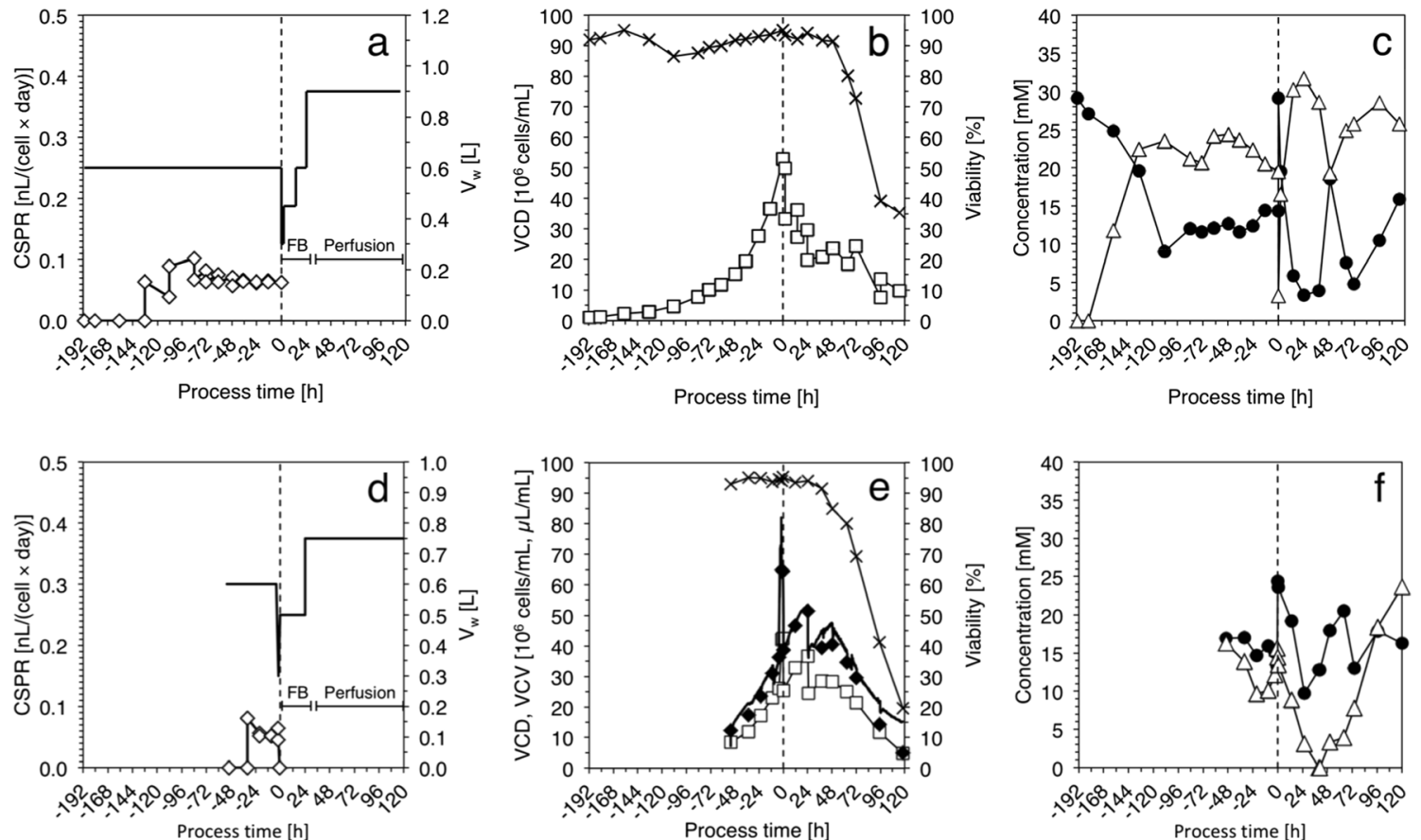

Fig. 1 Cultivation parameters and cell growth for two hybrid FB/ perfusion variants, Hybrid $1(\mathbf{a}-\mathbf{c})$ and Hybrid $2(\mathbf{d}-\mathbf{f})$, for the production of MVA-CR19 virus at high cell density. a, d Cell-specific perfusion rate, CSPR, (empty diamonds) and working volume, $V_{\mathrm{w}}$, (continuous line). b, e Viable cell density, VCD (squares); on-line

viable cell volume, VCV (continuous line); off-line VCV (full diamonds) (for VCV calculations see "Materials and Methods" section), and viability (crosses). c, f Glucose (filled circles) and lactate (triangles) concentration. Time of infection, $0 \mathrm{~h}$ (vertical dashed line) 
process parameters during cell expansion (Table 1) and performance during virus propagation (Table 2 ) is presented in the "Results" section.

\section{Viruses}

All infections with MVA-CR19 virus were carried out with the working bank no. $22.08 .2013\left(4.41 \times 10^{8}\right.$ infectious units per $\mathrm{mL}(\mathrm{IU} / \mathrm{mL})$ ) derived from a virus seed (Jordan et al. 2013) kindly provided by ProBioGen AG. MVA-CR19 virus seed aliquots were treated for $1 \mathrm{~min}$ in a sonication water bath to break up virus aggregates, diluted in fresh medium with a volume equal to $5-6 \%$ of the bioreactor $V_{\mathrm{w}}$, and added to the cell culture to an MOI (multiplicity of infection) of $0.05 \mathrm{IU} /$ cell.

For all experiments with MVA-CR19 virus, the infectious titers were determined taking into account its potential application as a (live) viral vector (Jordan et al. 2013). Vaccinia viruses usually replicate in a highly cell-associated fashion. Therefore, for the quantification of total virus titers (intraand extracellular), the cell suspensions were treated for cell lysis. The lysates were obtained by three freeze/thaw cycles $\left(-80^{\circ} \mathrm{C} / \mathrm{RT}\right)$ followed by $1 \mathrm{~min}$ in a sonication water bath (45 kHz). Cellular debris was removed by centrifugation at $1500 \times g$ at room temperature for $10 \mathrm{~min}$. For the quantification of virus released by host cells into supernatant, the samples were centrifuged at $200 \times g$ at RT for $5 \mathrm{~min}$. The cell-free supernatant was also subjected to three freeze/thaw cycles before storage (Jordan et al. 2013). All virus samples were stored in aliquots of $0.5-1 \mathrm{~mL}$ at $-80^{\circ} \mathrm{C}$. The number of infectious units was determined as described previously by
Jordan et al. (2009) with a relative standard deviation of \pm $0.4 \mathrm{log}$. The resulting titers are expressed as IU $/ \mathrm{mL}$.

The studies with human influenza A virus were performed with MDCK-derived virus seed A/PR/8/34 H1N1 (Robert Koch Institute, Amp. 3138) that was adapted to CR.pIX cells after three passages. The infectious titer of the adapted virus seed was determined by a $\mathrm{TCID}_{50}$ assay as $1.48 \times 10^{7} \mathrm{IU} / \mathrm{mL}$. All bioreactor experiments were performed at an MOI of $1 \times$ $10^{-3}$ in the presence of $1 \times 10^{-6} \mathrm{U}$ trypsin/cell (Gibco, no. 27250-018; prepared in PBS to $500 \mathrm{U} / \mathrm{mL}$ ) to facilitate progress of infection. As opposed to MVA, the main application for influenza virus preparations is inactivated vaccine where the total concentration of the viral hemagglutinin protein as an antigen is decisive. For this reason, total virus particle concentrations were estimated by a hemagglutination (HA) assay as previously described by Kalbfuss et al. (2008). HA titers, expressed as log HA units per test volume (log HAU/ $0.1 \mathrm{~mL}$ ), were converted to virions $/ \mathrm{mL}$ assuming the binding of one virus particle per erythrocyte and an erythrocyte concentration of $2 \times 10^{7}$ cells $/ \mathrm{mL}$, by:

$c_{\text {virus }}=2 \times 10^{7} \times 10^{(\log \mathrm{HAU} / 0.1 \mathrm{~mL})}$

with $c_{\text {virus }}$ as the total virus concentration in virions $/ \mathrm{mL}$. The relative standard deviation of the method was $\pm 0.09 \log$ (HA units $/ 0.1 \mu \mathrm{L}$ ) (Kalbfuss et al. 2008).

The cell-specific virus yield $\left(Y_{\mathrm{v} / \mathrm{cell}}\right)$ was calculated based on the total (i.e., intra- and extracellular) number of infectious virus particles ( $\operatorname{vir}_{\mathrm{T}}$, infectivity assay) for MVA virus and on the total number of all virus particles ( $c_{\text {virus }}$, HA assay) for influenza A virus, taking into account the total number of viable cells at the time of sampling $\left(\right.$ cell $\left._{\mathrm{T}}\right)$. The latter differed

Table 2 Yields for different cultivation strategies during the virus propagation phase

\begin{tabular}{|c|c|c|c|c|c|c|c|c|}
\hline Cultivation & $\begin{array}{l}\text { Working } \\
\text { volume }[\mathrm{mL}]^{\mathrm{a}}\end{array}$ & $\begin{array}{l}\text { Hollow fiber } \\
\text { module }\end{array}$ & $\begin{array}{l}\text { Harvest } \\
\text { volume }[\mathrm{mL}]\end{array}$ & Harvest titer ${ }^{\mathrm{b}}$ & $t_{\mathrm{T}}[\mathrm{day}]^{\mathrm{c}}$ & $\begin{array}{l}\text { Maximum viable } \\
\text { cell number }\left[10^{9}\right]\end{array}$ & $Y_{\mathrm{v} / \text { cell }}{ }^{\mathrm{d}}$ & $\mathrm{P}_{\mathrm{V}}^{\mathrm{e}}$ \\
\hline \multicolumn{9}{|l|}{ MVA-CR19 virus } \\
\hline Perfusion* & 800 & $500 \mathrm{kDa}$ & 800 & $3.2 \times 10^{9}$ & 13.0 & 66.4 & 38 & $1.0 \times 10^{10}$ \\
\hline $\mathrm{FB}+$ daily harvest $(\mathrm{F}+\mathrm{D})^{*}$ & 60 & NA & 95 & $5.3 \times 10^{9}$ & 10.0 & 1.9 & 270 & $2.6 \times 10^{11}$ \\
\hline Hybrid 1 & 900 & $0.65 \mu \mathrm{m}$ & 900 & $1.0 \times 10^{10}$ & 10.9 & 21.9 & 410 & $1.3 \times 10^{11}$ \\
\hline Hybrid 2 & 750 & $065 \mu \mathrm{m}$ & 750 & $1.0 \times 10^{10}$ & 8.2 & 21.3 & 352 & $2.8 \times 10^{11}$ \\
\hline \multicolumn{9}{|l|}{ Influenza A virus } \\
\hline Hybrid & 810 & $0.65 \mu \mathrm{m}$ & 810 & $3.80 \times 10^{10}$ & 9.5 & 23.7 & 1300 & $5.43 \times 10^{11}$ \\
\hline Perfusion & 800 & $500 \mathrm{kDa}$ & 800 & $8.05 \times 10^{9}$ & 9.6 & 19.0 & 340 & $1.81 \times 10^{11}$ \\
\hline Batch & 800 & NA & 800 & $5.23 \times 10^{9}$ & 8.0 & 3.1 & 1344 & $6.53 \times 10^{11}$ \\
\hline
\end{tabular}

${ }^{\text {a }}$ For FB-based processes: maximum working volume

${ }^{\mathrm{b}} \mathrm{In} \mathrm{IU/mL}$ for MVA virus and total virions/mL(estimated from HA measurements) for influenza A virus

${ }^{\mathrm{c}}$ Total time from cell inoculation to maximum titer

${ }^{\mathrm{d}}$ Cell-specific virus yield in IU/cell for MVA virus and total virions/cell (from HA) for influenza A virus

${ }^{\mathrm{e}}$ Volumetric productivity in IU/(L $\times$ day) for MVA virus and virions/( $\mathrm{L} \times$ day) (from $\mathrm{HA}$ ) for influenza A virus

*Vazquez-Ramirez et al. (2018) 
from the number of viable cells at the time of infection since cell growth was typically observed up to $36-48 \mathrm{hpi}$.

Similarly, the volumetric productivity $\left(P_{\mathrm{V}}\right)$ was calculated considering $\operatorname{vir}_{\mathrm{T}}$, the total spent medium during cell growth and virus replication phase $\left(V_{\mathrm{T}}, \mathrm{L}\right)$, and the total process time ( $t_{\mathrm{T}}$, day), by:

$P_{\mathrm{V}}=\operatorname{vir}_{\mathrm{T}} /\left(V_{\mathrm{T}} \times t_{\mathrm{T}}\right)$

\section{Determination of cell and metabolite concentrations}

Samples of 6-8 $\mathrm{mL}$ from bioreactor cultures were taken with a syringe through a Luer-Lock-septum in 12 or 24-h intervals and stored at $-80^{\circ} \mathrm{C}$ until analysis. A validated assay using a Bioprofile 100 Plus (Nova Biomedical) was used to determine glucose and lactate concentrations as described previously (Lohr et al. 2009). Viable cell density (VCD, cells $/ \mathrm{mL}$ ), cell viability $(\%)$, and average cell diameter $(\mu \mathrm{m})$ were determined with the cell counter Vi-CELL ${ }^{\mathrm{TM}}$ XR (Beckman Coulter) using a previously validated measuring program with a relative standard deviation of $2.5 \%$ for AGE.CR and CR.pIX cells (Lohr 2014). Cells analyzed from a total of 100 images were clustered in diameter classes in the range of 8.1-29.9 $\mu \mathrm{m}$ for calculation of the total viable cell volume per culture volume (VCV, $\mu \mathrm{L} / \mathrm{mL}$ ) using the cell number and cell diameter distribution. For some cultivations, an Incyte ${ }^{\circledR}$ capacitance probe connected to an Arc View 265 controller (Hamilton Bonaduz AG) was evaluated for its performance to deliver on-line VCV data. The on-line system was configured to provide the cell culture's permittivity $(\varepsilon, \mathrm{pF} / \mathrm{cm})$, which correlates directly to the VCV. On-line permittivity was converted to VCV applying a correlation factor $\mathrm{VCV} / \varepsilon$ of 1.8 obtained from previous cultivations (data not shown).

\section{Results}

A strategy previously reported for production of MVA-CR19 virus at high cell densities in shake flasks (Vazquez-Ramirez et al. 2018) was transferred to a controlled stirred tank bioreactor with an ATF2 system for cell retention. The method transfer was investigated for production of MVA and influenza A virus.

\section{MVA-CR19 virus propagation using hybrid $\mathrm{FB} /$ perfusion}

For the MVA-CR19 virus, this process was adapted for its implementation in a $0.6-\mathrm{L}\left(V_{\mathrm{w}}\right)$ bioreactor. During the cell growth phase of variant "Hybrid 1", an actual CSPR of $0.068 \mathrm{~nL} /$ (cell $\times$ day) (Fig. 1a and Table 1) was obtained, which was comparable to the target $0.06 \mathrm{~nL} /($ cell $\times$ day $)$.
This perfusion rate enabled a cell expansion from 1 to $>$ $50 \times 10^{6}$ cells $/ \mathrm{mL}$ (Fig. 1b) with a $\mu_{\text {mean }}$ of $0.0211 / \mathrm{h}$ (Table 1). This was comparable to the assumed specific growth rate of $0.0261 / \mathrm{h}$ for perfusion and was within the range of $0.016-0.0231 / \mathrm{h}$ from previous reports for batch cultures (Lohr et al. 2012). Manual control of the CSPR during the cell growth phase also prevented any glucose limitation and the excessive accumulation of lactate (Fig. 1c).

As an alternative to the Hybrid 1, the Hybrid 2 was started at $8 \times 10^{6}$ cells $/ \mathrm{mL}$ and cultivated up to $26 \times 10^{6}$ cells $/ \mathrm{mL}$. The resulting CSPR and $\mu_{\text {mean }}$ were in average $0.057 \mathrm{~nL} /$ (cell $\times$ day) and $0.0241 / \mathrm{h}$, respectively (Table 1 ). These were also in accordance with the target values of $0.06 \mathrm{~nL} /$ (cell $\times$ day) and $0.026 \mathrm{1} / \mathrm{h}$. In contrast to the Hybrid 1 cultivation, the cell suspension was concentrated twofold before infection by reducing the working volume to $0.3 \mathrm{~L}$ (Fig. 1d), and one reactor volume was exchanged with fresh medium. This procedure shortened the cell growth phase to 2 days and obviated discarding half of the volume of the produced cell suspension (Fig. 1e). Afterwards, the already described hybrid strategy was applied. The on-line VCV monitoring implemented in Hybrid 2 correlated well with off-line measurements up to late stages of the MVA virus propagation phase (Fig. 1e). This demonstrated the robustness of on-line capacitance measurements when the VCD exceeds $40 \times 10^{6}$ cells $/ \mathrm{mL}$, and expanded measurement to stages where virus-induced cell damage and apoptosis are widely spread within the infected cell population. In general, both the manually controlled CSPR during the cell growth and the hybrid strategy applied during virus propagation prevented the glucose limitation and the excessive accumulation of lactate (Fig. 1f).

A maximum MVA-CR19 virus yield of $1.0 \times 10^{10} \mathrm{IU} / \mathrm{mL}$ was obtained at 96 hpi and 72 hpi for Hybrid 1 and Hybrid 2, respectively (Fig. 2). For Hybrid 1, the virus particles were harvested using the same ATF hollow fiber module $(0.65 \mu \mathrm{m}$ pore size) as in the cell growth phase, whereas for Hybrid 2 a $0.2-\mu \mathrm{m}$ module was used during the cell growth phase and replaced by a new $0.65-\mu \mathrm{m}$ module for perfusion and virus harvest at $36 \mathrm{hpi}$. The relatively low virus harvest observed in Hybrid 1 (Fig. 2a) suggested that membrane fouling might have occurred during the cell growth phase. Nevertheless, a similar maximum virus titer, cell-specific yield, and volumetric productivity were obtained compared to the reference process in shake flasks (Table 2, F+D), which involved daily harvesting of virus (Vazquez-Ramirez et al. 2018). Even more significant is the more than tenfold increase in both the cellspecific yield and the volumetric productivity of Hybrid 1 compared to the use of only perfusion during virus propagation (Table 2, Perfusion) (Vazquez-Ramirez et al. 2018). Given the suboptimal virus harvesting for Hybrid 1, the product collected in the permeate was not considered for the calculation of the cell-specific yield and the volumetric productivity. 
Fig. 2 Progression of the MVACR19 virus production for two hybrid FB/perfusion variants, Hybrid 1 (a) and Hybrid 2 (b). Virus titers of whole cell lysates (filled circles) and permeate (crosses) are indicated for both variants. Virus titers in the supernatant (triangles) were determined only for Hybrid 2 (b). Arrows: time points of bolus feeding

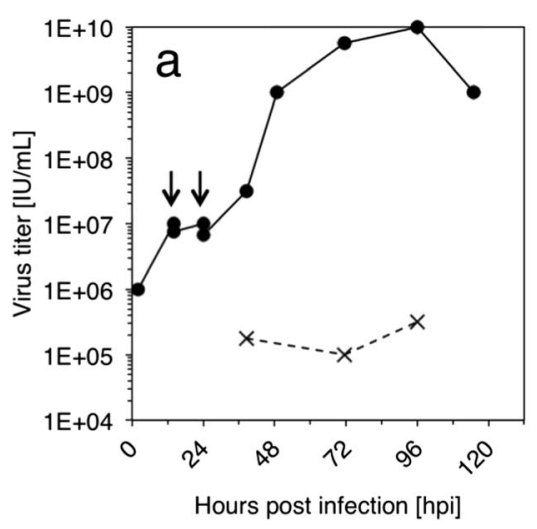

For Hybrid 2, almost all infectious virions were found in the culture supernatant with a maximum virus titer of $1 \times$ $10^{10} \mathrm{IU} / \mathrm{mL}$ (72 hpi, Fig. 2b). This is in agreement with previous reports (Jordan et al. 2013; Vazquez-Ramirez et al. 2018). Changing the hollow fiber module during the virus production phase enabled a quantitative harvest of virus particles from the supernatant only during the first $12 \mathrm{~h}$ of perfusion (i.e., 36-48 hpi) (Fig. 2b). From 48 hpi, the virus particle concentration in the permeate decreased considerably with respect to the apparent virus content in the culture supernatant. The virus titer in the permeate reached $1 \times 10^{6} \mathrm{IU} / \mathrm{mL}$ at $72 \mathrm{hpi}$, when the maximum virus titer of $1 \times 10^{10} \mathrm{IU} / \mathrm{mL}$ was reached in the culture supernatant (Fig. 2b). A further decrease in the permeate virus concentration to $1 \times 10^{5} \mathrm{IU} /$ $\mathrm{mL}$ was observed up to $120 \mathrm{hpi}$, while the titer in the bioreactor remained almost stable in the order of $10^{9} \mathrm{IU} / \mathrm{mL}$ (Fig. $2 \mathrm{~b}$ ). Similar to the Hybrid 1 cultivation, these observations suggest significant membrane fouling at $48 \mathrm{hpi}(24 \mathrm{~h}$ after begin of perfusion), preceding the most productive period of the virus propagation phase that occurs $48-72$ hpi (Fig. 2b). This phase also coincides with a fast drop of cell viability and, very likely, with increasing in cell lysis. The resulting massive accumulation of cell debris and the aggregation of MVA-CR19 viral particles (200-400 nm) may eventually have led to the obstruction of the ATF membrane $(0.65 \mu \mathrm{m}$ nominal pore size $)$. Maximum titers were reached $72 \mathrm{hpi}$, and infectious virions appeared to remain stable in the supernatants and as well in the total cell lysates, as no obvious decay in titers was observed up to 120 hpi (Fig. 2b).

Despite the differences in the feeding profile during the FB, the Hybrid 2 variant was as productive as Hybrid 1 (Table 2). In particular, a cell-specific virus yield of $352 \mathrm{IU} /$ cell and a volumetric productivity of $2.8 \times 10^{11} \mathrm{IU} /(\mathrm{L} \times$ day $)$ were obtained. Similar to the Hybrid 1 variant, a very low amount of product was collected in the permeate line and, therefore, was neglected for the calculations of the cell-specific yield and the volumetric productivity. The reduced process time of Hybrid 2 (8.2 days) led to a twofold higher volumetric productivity compared to cultivation Hybrid 1. However, virus yields in the order of $10^{11} \mathrm{IU} /(\mathrm{L} \times$ day $)$ would still be expected for a process operated at a similar time period as cultivation Hybrid 1 (10.9 days). As the cell-specific virus yields were comparable to Hybrid 1 (Table 2), the use of both strategies seems reasonable.

\section{Influenza $A$ virus propagation using hybrid $\mathrm{FB} /$ perfusion}

An earlier study that investigated factors interfering with the production of influenza A virus at HCD gave only partial solutions regarding productivity optimization (Genzel et al. 2014). Perfusion bioreactors were optimized in this earlier study with the avian cell line AGE1.CR in such a way that the cell-specific virus yields increased. However, overall volumetric productivity of these processes was higher in batch cultivations performed at conventional cell densities. The AGE1.CR cell line is the parental cell line of CR.pIX cells and has shown higher productivities for influenza A virus. In contrast, the productivity was slightly lower for MVA virus compared to CR.pIX cells (Jordan et al. 2009; Lohr et al. 2009).

Accordingly, it was investigated next whether the hybrid FB/perfusion strategy established for MVA virus in this study could also be used for improving the volumetric productivity of influenza A/PR/8/34 (H1N1) virus in CR.pIX cells at HCD. In addition, an alternative perfusion control was evaluated for the cell growth phase based on the glucose consumption, lactate accumulation, and the resulting medium acidification. To accomplish this, harvest and medium feeding pumps were activated when $\mathrm{pH}$ dropped to values below 7.2 and turned off when the $\mathrm{pH}$ increased to 7.2. Under this condition, glucose is replenished at the same time that lactate is removed from the bioreactor. This perfusion control allowed for an average CSPR of $0.119 \mathrm{~nL} /($ cell $\times$ day) (Table 1, Fig. 3a) and cell viabilities above $92 \%$ (Fig. 3b). Additionally, it enabled to maintain glucose concentrations above $10 \mathrm{mM}$ (Fig. $3 \mathrm{c})$, similar to a previous report in shake flasks, where the $\mathrm{pH}$ was controlled in a range of $7.2 \pm 0.2$ when applying a CSPR of $0.06 \mathrm{~L} /($ cell $\times$ day) with fresh CD-U3 medium (VazquezRamirez et al. 2018). Different to the HIPCOP strategy 

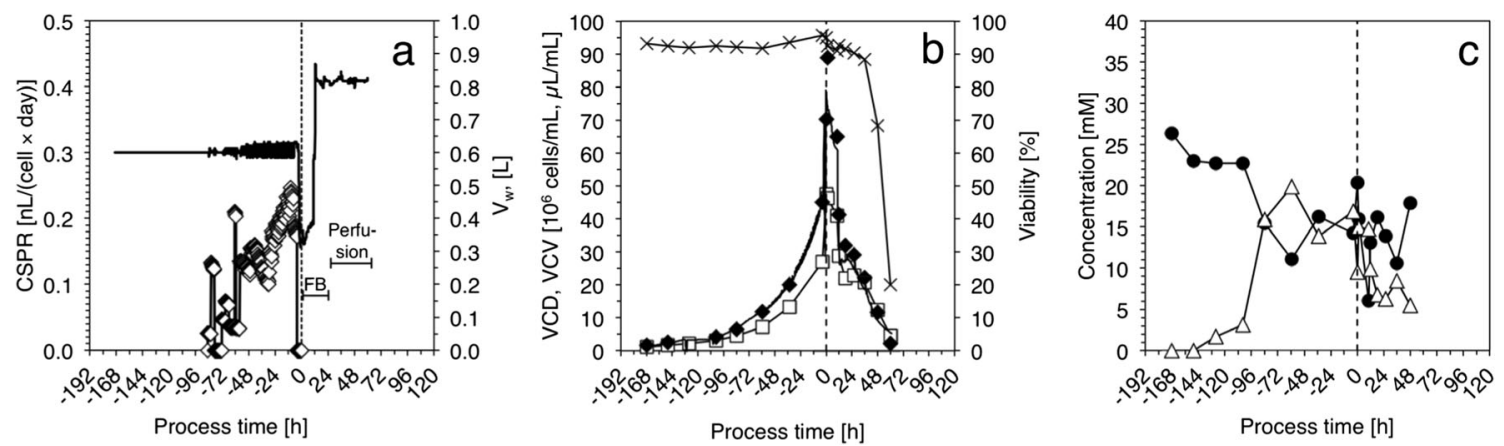

Fig. 3 Cultivation parameters and cell growth for a hybrid FB/perfusion process for the poduction of influenza $\mathrm{A} / \mathrm{PR} / 8 / 34$ (H1N1) virus at high cell density. a Cell-specific perfusion rate, CSPR, (empty diamonds) and working volume, $V_{\mathrm{w}}$ (continuous line). b Viable cell density, VCD (squares); on-line viable cell volume, VCV (continuous line); off-line

proposed by Hiller et al. (2017), which operates at glucose limitation and a lactate consumption regime in $\mathrm{CHO}$ cell cultivations, this strategy allowed for a perfusion control without reaching low glucose concentrations that might negatively affect the growth of CR.pIX cells.

After the CR.pIX cells were cultivated to $27 \times 10^{6}$ cells/ $\mathrm{mL}$, the $V_{\mathrm{w}}$ was reduced from 0.6 to $0.3 \mathrm{~L}$ and 1 reactor volume was exchanged with fresh medium before virus infection (Fig. 3a). A final concentration of $47 \times 10^{6} \mathrm{cells} / \mathrm{mL}$ was measured just before infection (Fig. 3b). Influenza A viruses are reported to replicate rapidly in CR.pIX cells (Jordan et al. 2016; Lohr et al. 2009). An increase in HA titers is typically observed at about 6 hpi and, depending on the virus strain, maximum titers are obtained 24-36 hpi (Lohr et al. 2009). Based on this information, and in contrast to the production of MVA virus, the FB phase was shortened (0-12 hpi), followed by a perfusion phase at a rate of one reactor volume per day (Fig. 3a). A process operated completely in perfusion and with total virus retention, as proposed by Genzel et al. (2014), was performed as a reference process (Online Resource 1).

The hybrid cultivation yielded a maximum HA titer of $3.3 \log \mathrm{HAU} / 100 \mu \mathrm{L}\left(3.8 \times 10^{10}\right.$ virions $\left./ \mathrm{mL}\right)$ at $60 \mathrm{hpi}$ (Fig. 4). This represented a fivefold increase compared to the reference perfusion cultivation (Fig. 4). Compared to a conventional batch process (Table 2), the increase was sevenfold.

\section{Discussion}

The implementation of the hybrid strategy in benchtop bioreactors showed a similar performance compared to analogous experiments in shake flasks and led to a clear improvement of virus yields towards perfusion (for HCD) and batch (for conventional cell densities). Next, broader benefits in relation to reported production strategies with different cell substrates
VCV (full diamonds) (for VCV calculations see "Materials and Methods" section), and viability (crosses). c Glucose (filled circles) and lactate (triangles) concentration. Time of infection, $0 \mathrm{~h}$ (vertical dashed line)

and its advantages for a potential industrial application were analyzed.

\section{MVA-CR19 virus propagation using hybrid FB/perfusion}

Although CD-U3 medium was not developed for perfusion processes (Jordan et al. 2011), medium consumption to achieve concentrations of about $50 \times 10^{6}$ cells $/ \mathrm{mL}$ with CSPR-based perfusion was moderate $(6.15$ reactor volumes for Hybrid 1 and 1.98 reactor volumes for Hybrid 2). Despite the low medium utilization, the average cell-specific growth rates for both Hybrid 1 and 2 cultivations were comparable to the $0.023 \mathrm{1} / \mathrm{h}$ achieved previously in shake flasks (VazquezRamirez et al. 2018). Accordingly, it also took only about 8 days to reach a minimum VCD of $50 \times 10^{6}$ cells $/ \mathrm{mL}$. Petiot et al. (2011) reported a medium utilization of about 3.5 reactor volumes to expand HEK293 cells within 9 days from 0.25 to $15 \times 10^{6}$ cells $/ \mathrm{mL}$ (before infection with

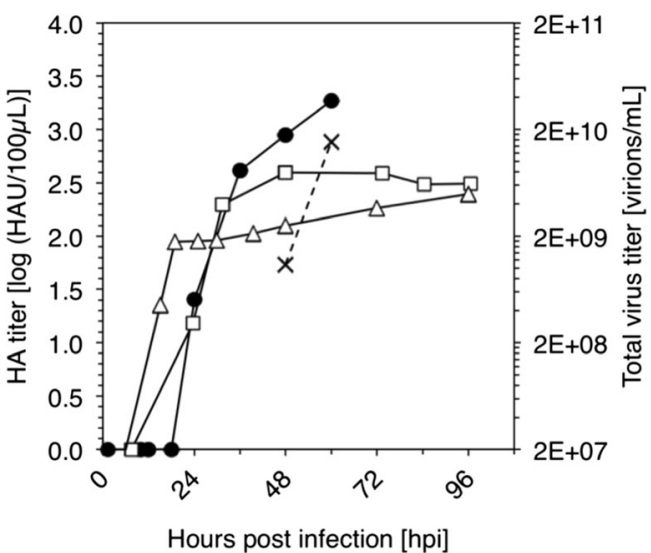

Fig. 4 Progression of influenza A/PR/8/34 (H1N1) virus production for different cultivation strategies. HA titers and the corresponding total number of virions $/ \mathrm{mL}$ are indicated for hybrid $\mathrm{FB}$ /perfusion (bioreactor supernatant: filled circles, permeate: crosses), perfusion (squares), and batch (triangles) 
influenza virus). Genzel et al. (2014) reported a medium consumption of 11.3 reactor volumes to propagate AGE1.CR cells to $50 \times 10^{6}$ cells $/ \mathrm{mL}$ before infection with influenza virus. Therefore, the results here represent a significant reduction in medium consumption before virus infection, which is an important contribution towards lower COGs in large-scale production.

Both Hybrid 1 and Hybrid 2 variants simplify the production process because a single bioreactor can be used for cell expansion and virus propagation. In Hybrid 1 cultivation, one-half of the cell suspension $(0.3 \mathrm{~L})$ was removed before infection at $50 \times 10^{6}$ cells/mL (Fig. 1 a). This cell suspension could possibly be used to start a second bioreactor in parallel. In contrast, in the Hybrid 2 cultivation, cells were cultivated to $25 \times 10^{6}$ cells $/ \mathrm{mL}$ in $0.6 \mathrm{~L}$ and concentrated to $50 \times 10^{6}$ cells $/ \mathrm{mL}$ prior to infection (Fig. $1 \mathrm{~d}$ ). In both cases, the subsequent FB phase required the addition of almost three times the starting volume to avoid substrate limitations. This ratio was lower than the 1:4 reported by Pohlscheidt et al. (2008) for the high-yield production of Parapoxvirus ovis at large scale, which - in addition - required transferring the cell suspension to a second larger bioreactor to perform the dilution steps. Since the initial FB phase of the hybrid strategy seems to be a critical operation also for MVACR19 virus propagation (Vazquez-Ramirez et al. 2018), further studies could focus on the development of an optimized feed medium to enable a higher starting volume (preferably $60 \%$ of the maximum working volume) and a lower maximum dilution ratio (about 2:3) to simplify the hybrid strategy for implementation in large-scale bioreactors.

Overall, the established hybrid strategies for MVA-CR19 virus production (Table 2, Hybrid 1 and Hybrid 2) resulted in a 10 to 100-fold increase in virus titers compared to the current standard production platform in CEF cells (Gilbert et al. 2005; Meiser et al. 2003). With respect to cultivations performed at conventional cell densities using CR.pIX cells (Jordan et al. 2009; Lohr et al. 2009; Lohr 2014), EB14 cells (Guehenneux and Pain 2005), and EB66 cells (Léon et al. 2016), up to tenfold higher titers were obtained. Cell-specific virus yields obtained with the hybrid strategies (410 and 352 IU/cell) were also competitive regarding the $500 \mathrm{IU} /$ cell obtained with $\mathrm{CEF}$ cells (Carroll and Moss 1997), the 50-200 IU/cell with CR.pIX cells (Lohr 2014), and the 25-50 IU/cell with EB66 cells (Léon et al. 2016) at conventional lower cell densities. Batch production of MVA virus with CR.pIX cells (Jordan et al. 2009; Lohr 2014) and EB66 cells (Léon et al. 2016) requires more or less the same time and the same media volumes. Accordingly, its volumetric productivity of about $2.0 \times 10^{10} \mathrm{IU} /(\mathrm{L} \times$ day $)$ is clearly surpassed by the 1.3 and $2.8 \times 10^{11} \mathrm{IU} /(\mathrm{L} \times$ day $)$ obtained with the hybrid strategy. Applying such a strategy would allow for 100,000 doses per liter of cell-free supernatant, considering that single doses of $1 \times 10^{8}$ PFU ( $\left.1 \mathrm{PFU}=1 \mathrm{IU}\right)$ per individual are currently used in clinical studies involving recombinant MVAbased vaccines (Gomez et al. 2013).
Due to its application as a viral vector, maintaining the infectious activity of MVA is a critical quality attribute. It is promising that titers were found to remain stable from 72 to 120 hpi (Fig. 2b). This suggests a low virus inactivation rate for the specific cultivation conditions chosen. While continuous virus harvesting failed for the chosen ATF system, the use of other cell retention devices including acoustic filter and settlers might be evaluated again for large-scale production to avoid product losses. One major property of the MVA-CR19 virus, its capacity to propagate in true single-cell suspension cultures, may additionally help to facilitate the recovery of infectious units directly from the culture supernatant without the need of cell disruption (Jordan et al. 2013). The Hybrid 2 cultivation showed that the maximum titer at 72 hpi accounted entirely for virus in the supernatant (Fig. 2b) with most of the cells showing a viability $>70 \%$. Hence, a clarification step at this point with a carefully chosen cell retention system would suffice to recover the MVA-CR19 virus from the bioreactor. Based on the very high performance of the hybrid strategy in upstream processing and further options to reduce costs in downstream processing, it can be assumed that higher costs related to the implementation of "complex" perfusion processes (purchase of dedicated equipment and training of staff) can be more than compensated even at industrial scale.

\section{Influenza A virus propagation using hybrid FB/perfusion}

The perfusion control applied during the cell growth phase in the hybrid cultivation led to a $\mu_{\max }=0.0251 / \mathrm{h}$ and an overall $\mu_{\text {mean }}=0.019$, which were in accordance with previous HCD bioreactor cultivations (Table 1). Similar to the Hybrid 2 process for MVA-CR19 virus, on-line VCV estimations correlated well with off-line measurements up to late stages of the influenza A virus propagation phase (Fig. 3b). No glucose limitation nor significant lactate accumulation was observed for the pH-based perfusion control during the cell growth phase (Fig. 3c). The high average CSPR of $0.119 \mathrm{~nL} /($ cell $\times$ day) (Table 1, Fig. 3a) obtained in the cell growth phase led to an increase in medium consumption (16.7 reactor volumes) compared to the reference perfusion process (3.9 reactor volumes). Since the perfusion rates depended on the $\mathrm{pH}$ control of the cultivation, reducing the $\mathrm{pH}$ set point could further minimize the high medium exchange.

Despite the very high medium consumption, the hybrid strategy provided a cell-specific yield of 1300 virions/cell and a volumetric productivity of $5.4 \times 10^{11}$ virions/ $(\mathrm{L} \times$ day $)$ (Table 2). This observation confirms that the cell density effect can be circumvented by a hybrid strategy for influenza A virus-infected cultures. The difference of $17 \%$ in volumetric productivity, with respect to the batch cultivation, can be explained by the rather high medium consumption during the cell growth phase of the hybrid cultivation. Compared to the 
perfusion-only strategy, the hybrid FB/perfusion conferred a clear improvement in both cell-specific and volumetric productivity (Table 2), and showed comparable yields for influenza A virus with respect to the parental suspension cell line AGE1.CR (Genzel et al. 2014).

Process intensification by consequent use of HCD strategies in viral vaccine manufacturing can contribute to a stable supply of vaccines. In case conventional batch production processes are already established, the implementation of HCD strategies can significantly increase manufacturing capacities, e.g., in emerging and developing countries where vaccines are most urgently needed. A possible solution using a hybrid FB/ perfusion strategy during the virus production phase for MVA and influenza A virus in small stirred tank bioreactors is described here. The application of this strategy resulted in a 7to 20-fold increase in virus titers without compromising cellspecific yields and volumetric productivities that often hinder the establishment of intensified processes. The high titers of $10^{10} \mathrm{IU} / \mathrm{mL}$ obtained for MVA virus demonstrated, in particular, the potential of this approach as an alternative to the current technology that relies on primary chicken embryo fibroblasts as a substrate. The results achieved here for the two different viruses may be also instructive for modernization of conventional approaches in viral vaccine production.

Acknowledgements This project is financially supported by the Mexican National Council of Science and Technology (CONACyT) and the German Academic Exchange Service (DAAD).

Funding Information Open access funding provided by Max Planck Society.

\section{Compliance with ethical standards}

Conflict of interest This article does not contain any studies with human participants or animals performed by any of the authors.

The authors declare that they have no conflicts of interest.

Open Access This article is distributed under the terms of the Creative Commons Attribution 4.0 International License (http:// creativecommons.org/licenses/by/4.0/), which permits unrestricted use, distribution, and reproduction in any medium, provided you give appropriate credit to the original author(s) and the source, provide a link to the Creative Commons license, and indicate if changes were made.

Publisher's note Springer Nature remains neutral with regard to jurisdictional claims in published maps and institutional affiliations.

\section{References}

Altenburg AF, Kreijtz JHCM, de Vries RD, Song F, Fux R, Rimmelzwaan GF, Sutter G, Volz A (2014) Modified Vaccinia Virus Ankara (MVA) as production platform for vaccines against influenza and other viral respiratory diseases. Viruses-Basel 6:27352761. https://doi.org/10.3390/V6072735

Aunins JG (2000) Viral vaccine production in cell culture. In: Spier RE (ed) Encyclopedia of Cell technology. Wiley, New York, pp 1182-1217
Boukhebza H, Bellon N, Limacher JM, Inchauspe G (2012) Therapeutic vaccination to treat chronic infectious diseases: current clinical developments using MVA-based vaccines. Hum Vaccin Immunother 8:1746-1757. https://doi.org/10.4161/hv.21689

Brown SW, Mehtali M (2010) The avian EB66® cell line, application to vaccines, and therapeutic protein production. PDA J Pharm Sci Technol 64:419-425

Buckland BC (2015) The development and manufacture of influenza vaccines. Hum Vaccin Immunother 11(6):1357-1360. https://doi. org/10.1080/21645515.2015.1026497

Carroll MW, Moss B (1997) Host range and cytopathogenicity of the highly attenuated MVA strain of vaccinia virus: propagation and generation of recombinant viruses in a nonhuman mammalian cell line. Virology 238:198-211

Cebere I, Dorrell L, McShane H, Simmons A, McCormack S, Schmidt C (2006) Phase I clinical trial safety of DNA- and modified virus Ankara-vectored human immunodeficiency virus type 1 (HIV-1) vaccines administered alone and in a prime-boost regime to healthy HIV-1-uninfected volunteers. Vaccine 24:417-425. https://doi.org/ 10.1016/j.vaccine.2005.08.041

Clincke MF, Mölleryd C, Zhang Y, Lindskog E, Walsh K, Chotteau V (2013) Very high density of CHO cells in perfusionby ATF or TFF in WAVE bioreactor ${ }^{\mathrm{TM}}$ - Part I. Effect of the cell density on the process. Biotechnol Prog 29:754-767. https://doi.org/10.1002/btpr.1704

Cotter CA, Earl PL, Wyatt LS, Moss B (2017) Preparation of cell cultures and vaccinia virus stocks. Curr Protoc Mol Biol 117:16.16.116.16.18. https://doi.org/10.1002/cpmb.33

Deschênes JS, Desbiens A, Perrier M, Kamen A (2006) Use of cell bleed in a high cell density perfusion culture and multivariable control of biomass and metabolite concentrations. Asia Pac J Chem Eng 1:8291. https://doi.org/10.1002/apj.10

Genzel Y, Vogel T, Buck J, Behrendt I, Vazquez-Ramirez D, Schiedner G, Jordan I, Reichl U (2014) High cell density cultivations by alternating tangential flow (ATF) perfusion for influenza A virus production using suspension cells. Vaccine 32:2770-2781. https://doi.org/10. 1016/j.vaccine.2014.02.016

Gilbert SC (2013) Clinical development of modified vaccinia virus Ankara vaccines. Vaccine 31:4241-4246. https://doi.org/10.1016/j. vaccine.2013.03.020

Gilbert PA, Comanita L, Barrett J, Peters A, Szabat M, McFadden G, Dekaban GA (2005) Current status for high titre poxvirus stock preparation in CEF under serumfree medium conditions: implication for vaccine development. Cytotechnology 48:79-88. https://doi.org/ 10.1007/s10616-005-3795-y

Gilbert SC, Moorthy VS, Andrews L, Pathan AA, McConkey SJ, Vuola JM (2006) Synergistic DNA-MVA prime-boost vaccination regimes for malaria and tuberculosis. Vaccine 24:4554-4561. https://doi.org/ 10.1016/j.vaccine.2005.08.048

Gomez CE, Najera JL, Krupa M, Perdiguero B, Esteban M (2011) MVA and NYVAC as vaccines against emergent infectious diseases and cancer. Curr Gene Ther 11:189-217. https://doi.org/10.2174/ 156652311795684731

Gomez CE, Perdiguero B, Garcia-Arriaza J, Esteban M (2012) Poxvirus vectors as HIV/AIDS vaccines in humans. Hum Vaccines Immunother 8:1192-1207. https://doi.org/10.4161/hv.20778

Gomez CE, Perdiguero B, Garcia-Arriaza J, Esteban M (2013) Clinical applications of attenuated MVA poxvirus strain. Expert Rev Vaccines 12: 1395-1416. https://doi.org/10.1586/14760584.2013.845531

Guehenneux F, Pain B (2005) Production of poxviruses with adherent or non adherent avian cell lines. WO 2005/007840 A1

Hiller GW, Clark DS, Blanch HW (1993) Cell retention-chemostat studies of hybridoma cells-analysis of hybridoma growth and metabolism in continuous suspension culture in serum-free medium. Biotechnol Bioeng 42:185-195. https://doi.org/10.1002/bit. 260420206 
Hiller GW, Ovalle AM, Gagnon MP, Curran ML, Wang W (2017) Cellcontrolled hybrid perfusion fed-batch $\mathrm{CHO}$ cell process provides significant productivity improvement over conventional fed-batch cultures. Biotechnol Bioeng 114:1438-1447. https://doi.org/10. 1002/bit.26259

Jordan I, Vos A, Beilfuss S, Neubert A, Breul S, Sandig V (2009) An avian cell line designed for production of highly attenuated viruses. Vaccine 27:748-756. https://doi.org/10.1016/j.vaccine.2008.11.066

Jordan I, Northoff S, Thiele M, Hartmann S, Horn D, Howing K, Bernhardt H, Oehmke S, von Horsten H, Rebeski D, Hinrichsen L, Zelnik V, Mueller W, Sandig V (2011) A chemically defined production process for highly attenuated poxviruses. Biologicals 39:50-58. https://doi.org/10.1016/j.biologicals.2010.11.005

Jordan I, Horn D, John K, Sandig V (2013) A genotype of modified vaccinia Ankara (MVA) that facilitates replication in suspension cultures in chemically defined medium. Viruses-Basel 5:321-339. https://doi.org/10.3390/V5010321

Jordan I, John K, Howing K, Lohr V, Penzes Z, Gubucz-Sombor E, Fu Y, Gao P, Harder T, Zadori Z, Sandig V (2016) Continuous cell lines from the Muscovy duck as potential replacement for primary cells in the production of avian vaccines. Avian Pathol 45:137-155. https:// doi.org/10.1080/03079457.2016.1138280

Kalbfuss B, Knochlein A, Krober T, Reichl U (2008) Monitoring influenza virus content in vaccine production: precise assays for the quantitation of hemagglutination and neuraminidase activity. Biologicals 36:145161. https://doi.org/10.1016/j.biologicals.2007.10.002

Konstantinov K, Goudar C, Ng M, Meneses R, Thrift J, Chuppa S, Matanguihan C, Michaels J, Naveh D (2006) The "push-to-low" approach for optimization of high-density perfusion cultures of animal cells. Adv Biochem Eng Biotechnol 101:75-98. https://doi.org/ $10.1007 / 10016$

Le Ru A, Jacob D, Transfiguracion J, Ansorge S, Henry O, Kamen AA (2010) Scalable production of influenza virus in HEK-293 cells for efficient vaccine manufacturing. Vaccine 28:3661-3671. https://doi. org/10.1016/j.vaccine.2010.03.029

Léon A, David AL, Madeline B, Guianvarc'h L, Dureau E, ChampionArnaud P, Hebben M, Huss T, Chatrenet B, Schwamborn K (2016) The EB66® cell line as a valuable cell substrate for MVA-based vaccines production. Vaccine 34:5878-5885. https://doi.org/10. 1016/j.vaccine.2016.10.043

Lindsay DA, Betenbaugh MJ (1992) Quantification of Cell-culture factors affecting recombinant protein yields in Baculovirus-infected insect cells. Biotechnol Bioeng 39:614-618. https://doi.org/10. 1002/bit.260390605

Litwin J (1992) The growth of Vero cells in suspension as cell-aggregates in serum-free media. Cytotechnology 10:169-174. https://doi.org/ 10.1007/BF0057089

Lohr V (2014) Characterization of the avian designer cells AGE1.CR and AGE1.CR.pIX considering growth, metabolism and production of influenza virus and Modified Vaccinia Virus Ankara (MVA). Dissertation, Otto von Guericke University Magdeburg

Lohr V, Rath A, Genzel Y, Jordan I, Sandig V, Reichl U (2009) New avian suspension cell lines provide production of influenza virus and MVA in serum-free media: studies on growth, metabolism and virus propagation. Vaccine 27:4975-4982. https://doi.org/10.1016/j. vaccine.2009.05.083

Lohr V, Genzel Y, Jordan I, Katinger D, Mahr S, Sandig V, Reichl U (2012) Live attenuated influenza viruses produced in a suspension process with avian AGE1.CR.pIX cells. BMC Biotechnol 12:79. https://doi.org/10.1186/1472-6750-12-79

Maranga L, Brazao TF, Carrondo MJT (2003) Virus-like particle production at low multiplicities of infection with the baculovirus insect cell system. Biotechnol Bioeng 84:245-253. https://doi.org/10.1002/bit.10773
Mayr A (2003) Smallpox vaccination and bioterrorism with pox viruses. Comp Immunol Microbiol Infect Dis 26:423-430. https://doi.org/ 10.1016/S0147-9571(03)00025-0

Meiser A, Boulanger D, Sutter G, Krijnse Locker J (2003) Comparison of virus production in chicken embryo fibroblasts infected with the WR, IHD-J and MVA strains of vaccinia virus: IHD-J is most efficient in trans-Golgi network wrapping and extracellular enveloped virus release. J Gen Virol 84(6):1383-1392. https://doi.org/10.1099/vir.0.19016-0

Ozturk SS (1996) Engineering challenges in high density cell culture systems. Cytotechnology 22:3-16. https://doi.org/10.1007/BF00353919

Paillet C, Forno G, Kratje R, Etcheverrigaray M (2009) Suspension-Vero cell cultures as a platform for viral vaccine production. Vaccine 27: 6464-6467. https://doi.org/10.1016/j.vaccine.2009.06.020

Pau MG, Ophorst C, Koldijt MH, Schouten G, Mehtali M, Uytdehaag F (2001) The human cell line PER.C6 provides a new manufacturing system for the production of influenzavaccines. Vaccine 19:27162721. https://doi.org/10.1016/S0264-410X(00)00508-9

Petiot E, Jacob D, Lanthier S, Lohr V, Ansorge S, Kamen AA (2011) Metabolic and kinetic analyses of influenza production in perfusion HEK293 cell culture. BMC Biotechnol 11:84. https://doi.org/10. 1186/1472-6750-11-84

Pohlscheidt M, Langer U, Minuth T, Bödeker B, Apeler H, Hörlein HD, Paulsen D, Rübsamen-Waigmann H, Henzler HJ, Reichl U (2008) Development and optimisation of a procedure for the production of Parapoxvirus ovis by large-scale microcarrier cell culture in a nonanimal, non-human and non-plant-derived medium. Vaccine 26: 1552-1565. https://doi.org/10.1016/j.vaccine.2008.01.032

Pollock J, Ho SV, Farid SS (2013) Fed-batch and perfusion culture processes: economic, environmental, and operational feasibility under uncertainty. Biotechnol Bioeng 110:206-219. https://doi.org/10. 1002/bit.24608

Soema PC, Kompier R, Amorij JP, Kersten GF (2015) Current and next generation influenza vaccines: formulation and production strategies. Eur J Pharm Biopharm 94:251-263. https://doi.org/10.1016/j. ejpb.2015.05.023

Stickl H, Hochstei V, Mayr A, Huber HC, Schafer H, Holzner A (1974) MVA Vaccination against Smallpox - Clinical Tests with an Attenuated Live Vaccinia Virus Strain (MVA). Dtsch Med Wochenschr 99:2386-2392. https://doi.org/10.1055/s-0028-1108143

Tapia F, Vazquez-Ramirez D, Genzel Y, Reichl U (2016) Bioreactors for high cell density and continuous multi-stage cultivations: options for process intensification in cell culture-based viral vaccine production. Appl Microbiol Biotechnol 100:2121-2132. https://doi.org/10. 1007/s00253-015-7267-9

Vazquez-Ramirez D, Genzel Y, Jordan I, Sandig V, Reichl U (2018) Highcell-density cultivations to increase MVA virus production. Vaccine 36:3124-3133. https://doi.org/10.1016/j.vaccine.2017.10.112

Webster DP, Dunachie S, Vuola JM, Berthoud T, Keating S, Laidlaw SM (2005) Enhanced T cell-mediated protection against malaria in human challenges by using the recombinant poxviruses FP9 and modified vaccinia virus Ankara. Proc Natl Acad Sci U S A 102:48364841. https://doi.org/10.1073/pnas.0406381102

White KM, Ayllon J, Mena I, Potenski A, Krammer F, García-Sastre A (2018) Influenza B virus reverse genetic backbones with improved growth properties in the EB66® cell line as basis for vaccine seed virus generation. Vaccine 36:1146-1153. https://doi.org/10.1016/j. vaccine.2018.01.050

Yang WC, Lu J, Kwiatkowski C, Yuan H, Kshirsagar R, Ryll T, Huang YM (2014) Perfusion seed cultures improve biopharmaceutical fedbatch production capacity and product quality. Biotechnol Prog 30: 616-625. https://doi.org/10.1002/btpr.1884

Yang WC, Minkler DF, Kshirsagar R, Ryll T, Huang YM (2016) Concentrated fed-batch cell culture increases manufacturing capacity without additional volumetric capacity. J Biotechnol 217:1-11. https://doi.org/10.1016/j.jbiotec.2015.10.009 